\title{
Comparison of Student Learning Outcomes Through Video Learning Media with Powerpoint
}

\author{
Illa Mudasih ${ }^{1}$, Waspodo Tjipto Subroto ${ }^{2}$
}

\begin{tabular}{l} 
ARTICLE INFO \\
\hline Article History: \\
Received 15.10.2018 \\
Received in revised form \\
03.01 .2019 \\
Accepted \\
Available online 01.04 .2019
\end{tabular}

\begin{abstract}
This research is an experimental study with a type of True Experimental research. The design carried out in this study was the design of the pretest-posttest control group design. Determination of the sample using a random sampling system while the data-collection technique was using test, that are pre-test and post-test. The class XII AK 1 as the experimental class 1 (video media) and class XII AK II (powerpoint media) as the experimental class 2. The normality test data was analyzed by using the pretest value on the use of video media with a signific ant level of 0.388 and on the use of a significant level powerpoint media of 0.059 , it was stated that the two significant levels were normally distributed because they were greater than 0.05 . The homogeneity test results show that a signific ant level of pretest for both classes (video media and powerpoint media) is 0.436 and more than 0.05 . It also shows that the sample used has the same or homogeneous variance. The results of the statistical test with the Independent Sample T-test showed a signific ance level of $0.001<0.05$, indic ating that the results of the t-test $<$ signific ance level of 0.05 . In addition, it is known that tcount is 2.093 which indicates that tcount $>$ ttable $(2,093>0.408)$. So the hypothesis $\mathrm{H} 0$ is rejected and $\mathrm{H} 1$ accepted. So it can be concluded that there are differences in student learning outcomes using video media using powerpoint media.
\end{abstract}

Keywords: ${ }^{1}$

(C) IJERE. All rights resenved

Video Media, Powerpoint Media, Learning Outcomes.

\section{INTRODUCTION}

Education is a kind of need for every human being. Every human being needs education to improve his quality and every citizen has the right to get it. Purposeof the National Education itself according to the National Education System Law No. 20 of 2003, namely developing capabilities and forming national character and civilization that aredignified in order to educate the nation. Therefore, to develop an advanced nation, the quality of education that is able to compete in the globalization era is needed. Education is rooted in national culture, where the process of education is a process of developing potential students so that they are able to become heirs and developers of national culture (Daryanto, 2014). To lead to the success of education in Indonesia, the government has made its best efforts by replacing the previous curriculum with 2013 Curriculum in the hope of being able to meet the needs and quality of education that is better and in accordance with the needs of the field.

According to Ridw an (2015), the 2013 curriculum defines Graduates Competency Standards (SKL) as they should be, namely criteria regarding the qualifications of graduates' abilities which include attitudes, knowledge and skills. To realize this, the 2013 curriculum implementation teachers are required to be professional in designing effective and meaningful learning, organizing learning, choosing the right learning approach, determining learning procedures and competency formation effectively, and establishing criteria for learning success. Learning is a business process carried out by a person to obtain a change in new behavior as a whole, as a result of his own experience in interaction with his environment (Slameto, 2015). For that we need an innovative and creative teaching and learning process so that students are more interested and easy to understand the learning that is conveyed.

\footnotetext{
${ }^{1}$ Corresponding e-mail:illa18.0003@mhs.unesa.ac.id ${ }^{1}$, orcid.org/0000-0003-3371-8193 waspodosubroto@unesa.ac.id2; orcid.org/0000-0002-1477-1653 Posgraduate, Universitas Negeri Surabaya ${ }^{1}$, Senior Lecture, Universitas Negeri Surbaya ${ }^{2}$
} 
Mudasih,I. \& Subroto,W.T. (2019). Comparison of student learning outcomes through video learning media with powerpoint. International Journal of Educational Research Review, 4(2),183-189.

The development of technology is now very close to students, this is caused because in the globalization era, Indonesian society cannot avoid the high changes or innovations due to the rapid development of information technology in various fields of life, especially its influence on the world of education. Argues that the use of learning media in the learning process can generate new desires and interests, generate motivation and stimulation of learning activities, and even bring psychological influences to students (Arsyad, 2016). The position of learning media is in the learning model as an effort to enhance the process of interaction and communication between teachers and students with their learning environment. Media has a function as a tool, to help achieve learning goals. This is based on the belief that the teaching and learning process by using media enhances students' learning activities in a long period of time. That means students' learning activities with the help of the media will produce better learning processes and results compared to without media assistance. Learning outcomes are the ultimate goal to achieve as the manifestation of change after going through a long process of teaching and learning activities(Istuningsih, et al., 2018).

Based on the results of observations made at SMK Wachid Hasyim 2 Surabaya that for learning in factory overhead material, students learn with the help of books, media powerpoint and teacher explanations. Powerpoint is a presentation tool, usually used to explain things that are summarized and packaged in powerpoint slides. In the use of this media students tend to be easily bored, this needs to be improved learning media that are used to facilita te students in understanding the subject matter. Efforts to improve learning can be done externally with teachers to renew learning, especially those related to efforts to improve student learning outcomes are low (Saputri, et al, 2018). The next step in the learning process will be to use video media inlearning material overhead factory. Sadiman (2014), video media as an audio visual media that displays motion. Based on previous research Ade (2014) states that using video learning media can improve student learning outcomes. Based on the results of the description above, researchers are interested in conducting research with the title "Comparison of Student Learning Outcomes through Video Learning Media with Powerpoints". The purpose of this research is to determine the difference in learning outcomes of students of class XII AK in the factory overhead material using video media with powerpoint.

\section{REVIEW OF THEORY}

Media comes from the word medium that has an introductory meaning or intermediary, thus it can be interpreted that the media is a vehicle for channeling learning information or channeling messages (Saifuddin, 2014). Media is everything that can be used to channel the contents of messages, from senders to recipients so that they can stimulate, thoughts, feelings, attention and interests and attention of students in such a way that the learning process occurs (Sadiman, 2014). Whereas Daryanto (2014) says, in the learning process the media has a function as a carrier of information from the source (teacher/educator) to the recipient (students/students). Based on some of the opinions above, it is concluded that the media is everything that can stimulate thoughts, feelings, attention and interests and interests of students in such a way that students are able to obtain knowledge, skills, and attitudes. that the types of learning media are printed, audio-visual, graphic and silent projections. Before the media is determined, the selection of learning media should have criteria (Arsyad, 2016) that is in accordance with the objectives to be achieved, right to support the content of the study of facts, concepts, principles, or generalizations, practical, flexible and enduring. use it, group goals and technical quality. Learning media also has the benefit of clarifying the message so that it is not too verbality and overcomes the limitations of space, time, energy, and sense power (Daryanto, 2016).

Microsoft Power Point is a computer program devoted to presentations. Erlina (2009) says, pow er point media helps teachers in presenting and clarifying subject matter with varied activities and an atmosphere that is not boring. A variety of power point media features can be chosen, namely giv ing graphics and images, text, photos, sounds, inserting word art, setting the transition model when there is a

www.ijere.com 
Mudasih,I. \& Subroto,W.T. (2019). Comparison of student learning outcomes through video learning media with powerpoint. International Journal of Educational Research Review, 4(2),63-69.

transition from one slide to the next slide, adding patterns, adjusting the text color, giving a shadow, create charts and organizational charts. while the video media is an image in the frame, where frame by frame is projected through the projector lens mechanically so that the screen shows a vivid image (Arsyad, 2016). From this understanding it can be concluded, that video is one ty pe of audio-visual media that can describe an object that moves together with a natural sound or an appropriate sound. Videos can present information, explain processes, explain complex concept concepts, teach skills, abbreviate or extend time, and influence attitudes. Based on the above understanding, it can be formulated that video media is a human intermediary tool to convey or channel messages, ideas, ideas, opinions using images and sounds so that they can stimulate the sense of sight and hearing so that the inten ded person is more interested.

Based on the problem, the theoretical study described above, the hypothesis in the research proposed is $\mathrm{H1}$, there are differences in student learning outcomes between classes given treatment using video learning media and classes that are given treatment using Pow er point learning media. Previous research that supports this research is research from Fiona (2018), the results of the study show that the average learning outcomes in class $\mathrm{X} 1$ (Pow toon) are 86,774 while class $\mathrm{X} 2$ (powerpoint) is 80,968 . Hypothesis test results show a significance level of $0.027<0.05$ so that there is a comparison of learning outcomes between classes using pow erpoint and powtoon.

\section{METHODS}

This study uses experimental research with a type of True Experimental research. Experimental research is a study that is used to find the effect of certain treatments on others in controlled conditions (Sugiyono, 2016). So, experimental research means finding the influence of a variable that gets treatment. The design carried out in this study was the design of the pretest-posttest control group design.

Table 1. Research Design Draft

\begin{tabular}{|c|c|c|c|}
\hline Class & Pre-test & Treatment & Post-test \\
\hline Experiment 1 & $\mathrm{O}_{1}$ & $\mathrm{X}_{1}$ & $\mathrm{O}_{3}$ \\
\hline Experiment 2 & $\mathrm{O}_{2}$ & $\mathrm{X}_{2}$ & $\mathrm{O}_{4}$ \\
\hline
\end{tabular}

Description:

$\mathrm{O}_{1}=$ Pre-test $w$ hich is a test given to students before teaching and learning activities using media video.

$\mathrm{O}_{2}=$ Pre-test which is a test given to students before teaching and learning activities using powerpoint media.

$\mathrm{O}_{3}=$ Post-test is a test given to students after teaching and learning activit ies using video media.

$\mathrm{O}_{4}=$ Post-test is a test given to students after teaching and learning activities using pow erpoint media.

Based on table 1 for data $\mathrm{O}_{1}$ and $\mathrm{O}_{2}$ analyzed using normality, homogeneity. Whereas $\mathrm{O}_{3}$ and $\mathrm{O}_{4}$ were carried out a comparison test, namely the $t$-test of two parties to find out student learning outcomes. This research was conducted at SMK Wachid Hasyim 2 Surabaya in the first semester of school year 2018 2019, research sampling was conducted randomly using a random sampling system, so taking 2 objects taken randomly regardless of the strata of the total 3 classes in class XII AK 1, XII AK 2, and XII AK 3 SMK Wachid Hasyim 2 Surabaya. The sample in this study consisted of students of Class XII Accounting 1 with 36 female students and 1 male student as experimental class 1. The class XII Accounting 2 with 37 all female students as experimental class 2 . The researcher chose the samplebecause the researcher taught at that location.

\section{Material}

The research instrument is a data collection tool when conducting research using a method (Arikunto, 2014). The research instruments in this study are documentation sheets and test sheets. The 
Mudasih,I. \& Subroto,W.T. (2019). Comparison of student learning outcomes through video learning media with powerpoint. International Journal of Educational Research Review, 4(2),63-69.

documentation sheet consists of learning tools, namely syllabus about factory ov erhead costs and lesson plans (RPP). While the test sheet used in this study is that students are given a multiple choice test, the test used is in the form of the initial ability test (pretest) before treatment of students. Then the final ability test (posttest) after students get treatment.

\section{Data Analyses}

Data analysis techniques used are normality test, homogeneity test, and hypothesis test. Before conducting a hypothesis test, first perform a normality test and homogeneity test. Homogeneity test is a test to determine whether the sample variance used is homogeneous (Arikunto, 2014). In testing homogeneity can be done by lavene test with the SPSS version 16 program, which is tested is the value of learning outcomes with testing criteria if $\mathrm{P}$-Value (more than) the significance level of $5 \%$. While for the normality test is a test of data that determines whether the control class and the experimental class before getting treatment and after getting treatment is normally distributed or not. The Normality Test used in this study is the Chi-Square test using SPSS version 16, where the data tested results from the pretest and posttest of the control class and the experimental class. If the data is normally distributed then the probability or $\mathrm{p}$-value $>$ significance level $(\alpha)$ is $0.05(5 \%)$. After that, the $t$ test (hypothesis) in the study used the results of the pretest and posttest in the control class and the experimental class. The $t$ test (hypothesis) is used to determine whether there are differences in student learning outcomes with video learning media with powerpoint media between the control class and the experimental class. Hypothesis testing $w$ as tested using the $t$ test with the help of the SPSS 16 program.

\section{Findings}

Based on the observation results for manufacturing accounting learning companies, students learn with the help of books, powerpoint media and teacher explanations. The use of this media students tend to be easily bored. Students who are less active because the method used is teacher-centered learning. This needs to be improved using instructional media to facilitate students in understanding the subject matter. With this, researchers use media and pow erpoint media on learning activities.

This study tested two groups, namely the experimental group 1 and the experimental group 2 . In the experimental group 1 student was given treatment using video media and experimental group 2 was given treatment using powerpoint media. Learning activities were carried out for three meetings in the experimental group 1 in class XII AK 1 with the number of female students 36 and male students 37 . First meeting; students are given questions about the pretest of factory overhead material, second; students are given treatment by using video media with factory overhead material, third; students were given questions about posttes of factory overhead material. In the experimental class 2 learning activities were also held for three meetings with a number of female students 37 . Then the first meeting; students are given questions about the pretest of factory overhead material, second; students are given treatment using powerpoint media with factory overhead material, third; students are given questions about posttest factory overhead costs. Learning in each group is held for three meetings and each meeting lasts for 2 hours of lessons. This is given to test student learning outcomes using video media with pow erpoint media.

\section{RESULTS}

The results of research conducted in Surabaya SMK Wachid Hasyim 2 class XII AK 2018/2019 academic year with conditions of the initial ability of experimental class 1 and experimental class 2 homogeneous. This study begins with pretesting in the experimental class and the control class to determine the students' initial ability to factory overhead material. After the pretest, the results of the pretest were tested for normality and homogentias as a prerequisite test of the test.

Table 2. Test Results Normality

www.ijere.com 
Mudasih,I. \& Subroto,W.T. (2019). Comparison of student learning outcomes through video learning media with powerpoint. International Journal of Educational Research Review, 4(2),63-69.

StatisticsTest

\begin{tabular}{|l|r|r|}
\hline & pretest_video & pretest_pow erpoint \\
\hline Chi-Square & $6324 \mathrm{a}$ & $19108^{\mathrm{b}}$ \\
Df & 6 & 11 \\
Asymp.Sig. & .388 & .059 \\
\hline
\end{tabular}

a. 0 cells $(.0 \%)$ have less than 5 expected frequencies. The minimum expected cell frequency is 5.3 .

b. 12 cells $(100.0 \%)$ have less than 5 expected frequencies. The minimum expected cell frequency is 3.1 .

After testing the normality of the sample through the help of SPPS, the chi-square test for the value of the pretest video has a significance of 0.388 while the value of the pretest powerpoint has a significance of 0.059 . Then the two significance levels are normally distributed because they are greater than 0.05 .

The homogeneity test was conducted to find out the two samples (experimental class and control class) used in the study had homogeneous or non-homogeneous variants. The homogeneity test results for pretest data are as follows:

Table 3. Homogeneity Results

TestTest of Homogeneity of Variance

\begin{tabular}{|l|c|c|c|c|}
\hline & Levene Statistics & df1 & df2 & Sig. \\
\hline posttest Based on Mean & .613 & 1 & 72 & .436 \\
Based on Median & .360 & 1 & 72 & .551 \\
$\begin{array}{l}\text { Based on median and } \\
\text { with adjusted df } \\
\begin{array}{l}\text { Based on the mean } \\
\text { trimmed }\end{array}\end{array}$ & .360 & 1 & 71861 & .551 \\
\hline
\end{tabular}

After homogeneity test using SPSS with Lavene Statistics test, it is known that the significant level (sig) of the pretest of the two classes is 0.436 and more than 0.05 . It also show s that the sample used has the same or homogeneous variance. After knowing both classes are homogeneous, so drawing is done to determine the sample class. The drawing results are known that class XII Ak 1 as experimental class 1 (video media) and class XII Ak 2 as experimental class 2 (powerpoint media). The average value of Ak 1 pretest is 46.8 and the average value of the XII Ak 2 class pretest is 45 . After being pretested in both classes followed by learning with factory overhead costs. In the experimental class 1 learning using video media, experimental class 2 using powerpoint media and for the control class without treatment. At the end of learning, posttest $w$ as conducted to find out the student learning outcomes. The problem used is a question that has been tested so it is valid to use. After doing the posttest, different learning outcomes are obtained. The final results seen from the analysis of the value of the pretest and posttest showed the experimental class 1 before getting treatment obtained an average value of pretest of 46.8 and after being treated the average value of posttest 85 . As for the experimental class 2 before obtaining the average value of pretest 45 and after being treated the average value of posttest 79 . Then the posttest value between experiment 1 which uses video and postst value experimental class 2 which uses powerpoint hy pothesis testing is done to determine the differences in student learning outcomes. With thehy pothesis criteria as follows: 
Mudasih,I. \& Subroto,W.T. (2019). Comparison of student learning outcomes through video learning media with powerpoint. International Journal of Educational Research Review, 4(2),63-69.

$\mathrm{H} 0=$ There is no difference in student learning outcomes between classes given treatment using video learning media and classes given treatment using Powerpoint learning media.

$\mathrm{H} 1$ = There are differences in student learning outcomes between classes given treatment using video learning media and classes given treatment using Pow erpoint learning media.

Hypothesis testing is done by different tests to test the differences in learning outcomes from the posttest values between the two classes through the help of the SPSS program with the Independent Sample T-Test statistical test. For the average posttest of the experimental class 2 (powerpoint media) obtained by 79, while the average posttest experimental class 1 (video media) was 85 . Viewed from the results of posttest in the experimental class 1 (media video) and experimental class 2 (media pow erpoint) there are differences, where the experimental class 1 (video media) gets an average posttest value higher than the average value of the posttest experimental class 2 (pow erpoint media). Of the differences in the results of the posttest there are differences, but the differences cannot be said to be significant. With that the Independent Sample T-Test statistical test is conducted. The hypothesis test is as follows:

Table 4. Hypothesis Test Results

\begin{tabular}{|c|c|c|c|c|c|c|c|c|c|c|}
\hline & \multicolumn{10}{|c|}{ Independent Samples Test } \\
\hline & & \multicolumn{2}{|c|}{$\begin{array}{l}\text { Levene's Test for } \\
\text { Equality of } \\
\text { Variances }\end{array}$} & \multicolumn{7}{|c|}{ t-test for Equality of Means } \\
\hline & & \multirow[b]{2}{*}{$\mathrm{F}$} & \multirow[b]{2}{*}{ Sig. } & & \multirow[b]{2}{*}{$f$} & \multirow{2}{*}{$\begin{array}{l}\text { Sig. (2- } \\
\text { tailed) }\end{array}$} & \multirow{2}{*}{$\begin{array}{l}\text { Mean } \\
\text { Differenc } \\
\quad \mathrm{e}\end{array}$} & \multirow{2}{*}{$\begin{array}{l}\text { Std. Error } \\
\text { Differenc } \\
\quad \mathrm{e}\end{array}$} & \multicolumn{2}{|c|}{$\begin{array}{l}95 \% \text { Confidence } \\
\text { Interval of the } \\
\text { Difference }\end{array}$} \\
\hline & & & & & & & & & Lower & Upper \\
\hline Hasi Ibelajar & $\begin{array}{l}\text { Equal variances } \\
\text { assumed }\end{array}$ & .613 & .436 & .349 & 2 & .001 & 4.64865 & 1.38797 & 1.88178 & 7.41552 \\
\hline & $\begin{array}{l}\text { Equal variances } \\
\text { not assumed }\end{array}$ & & & .349 & 1.906 & .001 & 4.64865 & 1.38797 & 1.88172 & 7.41558 \\
\hline
\end{tabular}

By the criteria of the hypothesis $\mathrm{H}_{0}$ is no difference between the students' learning outcomes the class given treatment using video learning media and classes that were given treatment using learning media Powerpoint and $\mathrm{H}_{1}$ were there differences in student learning outcomes between classes given treatment using video learning media and classes given treatment using learning media Powerpoint. The results of the statistical test with the Independent Sample T-test showed a significance level of $0.001<0.05$, indicating that the results of the $t$-test $<$ significance level of 0.05 . In addition, it is know $n$ that $t_{\text {count }}$ is 2.093 which indicates that $\mathrm{t}_{\text {count }}>\mathrm{t}_{\text {table }}(2,093>0.408)$. So the hypothesis $\mathrm{H}_{0}$ is rejected and $\mathrm{H}_{1}$ accepted. It was concluded that the learning outcomes of the experimental group 1 using videos were different or not the same from the learning outcomes of the experimental group 2 students using powerpoint media with a significant level of 0.05 or a confidence level of $95 \%$. This means that there are significant differences in student learning outcomes in the use of video media with powerpoint media. So it can be concluded that there are differences in student learning outcomes using video media using powerpoint media. Due to using videos, it gives rise to more student interactions to understand the material with illustrations that are easy to understand.

\section{CONCLUSIONS}

The purpose of this study was to find out to find out the differences in learning outcomes of class XII AK students in factory overhead material using video media with powerpoint. Supported by previous research from Fiona (2018) that learning outcomes use lower pow erpoint compared to learning outcomes using powtoon. The conclusion of this study is that the learning outcomes of experimental class 
Mudasih,I. \& Subroto,W.T. (2019). Comparison of student learning outcomes through video learning media with powerpoint. International Journal of Educational Research Review, 4(2),63-69.

1 students by using video media on material factory overhead costs an average value of 85 . Then the experimental class 2 student learning outcomes using powerpoint media on factory overhead costs received an average value of 79 . So that there are differences in student learning outcomes between the experimental class, namely classes that use video media with powerpoint media in learning activities by obtaining significant levels of 0.001 and tcount abel $t$ table $(2,093>0.408)$. This research is limited to the learning process of factory overhead costs. Based on the results of data analysis and conclusions, it can be suggested a number of suggestions including in the learning process the use of instructional media is expected to be improved not only video and powerpoint media but also other media to encourage students to learn and in this study still have many shortcomings. media design so that further researchers are expected to add more interesting media updates.

\section{REFERENCES}

Ade (2014). Comparison of student social studies learning outcomes using video media versus image media. Jakarta: Hidayatullah Syarif State Islamic University.

Arikunto, S. (2014). Research procedure a practice approach. Jakarta: Rineka Cipta.

Arsyad, A. (2016). Learning media. Jakarta: PT Raja Grafindo Persada.

Daryanto (2014). Approach to scientific learning curriculum 2013. Yogyakarta: Gava Media.

Daryanto (2016). Learning media. Yogyakarta: Gava Media.

Erlina. (2009). Super media. Jakarta: Erlangga

Fiona (2018). Comparative Analysis of learning outcomes using powerpoint and powtoon based on problem based learning (Pbl) in the subject of class XI Tax administration at the state high school of Mojoagung. Journal of Accounting Education, 6 (3).

Government of the Republic of Indonesia (2003). Law of the Republic of Indonesia Number. 20 of 2003 concerning the National Education System, Jakarta.

Saputri,D.Y., Rukayah, \& Indriayu,M. (2018). Need assessment of interactive multimedia based on game in elementary school: A challenge into learning in 21st century. International Journal of Educational Research Review,3(3),1-8.

Ridwan (2015). Scientific learning for the implementation of 2013 Curriculum. Jakarta: Earth Literacy.

Sadiman, Arief S, et al. (2014). Educational media, understanding, development and utilization. Jakarta: Rajawali Press.

Saifuddin (2014). Management of theoretical and practical learning. Yogyakarta: Deepublish.

Istuningsih,W., Baedhowi,B.,E Sangka,K.B. (2018). The effectiveness of scientific approach using e-module based on learning cycle 7e to improve students' learning outcome. International Journal of Educational Research Review,3(3),75-85.

Slameto (2015). Learning and the affecting factors. Jakarta: Rineke Cipta.

Sugiyono (2016). Qualitative and quantitative research methods R ED. Bandung: Alfabet. 